\title{
AN INVESTIGATION OF MECHANICAL PROPERTIES OF RECYCLED COARSE AGGREGATE CONCRETE
}

\author{
DENG X.H. ${ }^{1}$, LU Z.L. ${ }^{2}$, LI P. $^{3}$, XU T. $^{4}$
}

Recycling construction and demolition waste not only reduces project costs; and saves natural resources, but also solves the environmental threat caused by construction waste disposal. In this paper, C25 waste road concrete is used as an experimental material, the uniaxial compression strength and tensile splitting strength of C25 RAC whose coarse aggregate replacement rate is $0 \%, 25 \%, 50 \%, 75 \%$, and $100 \%$ are tested under the condition that the water-to-cement ratio is $0.47,0.55$ and 0.61 . The results show: (1) the uniaxial compression strength and tensile splitting strength decrease with the increase of RAC; (2) for concrete with the same water-to-cement ratio, when the coarse aggregate replacement rate changes from $0 \%$ to $50 \%$, the uniaxial compression strength and tensile splitting strength of RAC changes slightly. When the coarse aggregate replacement rate changes from $50 \%$ to $100 \%$, the uniaxial compression strength and tensile splitting strength of RAC decreases rapidly.

Key words: recycled coarse aggregate concrete; water-to-cement ratio; coarse aggregate replacement rate; uniaxial compression strength; tensile splitting strength

\footnotetext{
1 Associate professor. School of Civil and Architecture Engineering, Xi'an Technological University, No. 2 of Xuefu Road in Xi'an, shaanxi, China, E-mail: dh_gl@163.com

2 School of Civil and Architecture Engineering, Xi' an Technological University, No. 2 of Xuefu Road in Xi'an, shaanxi, China, E-mail: luzelin1025@163.com

3 School of Civil and Architecture Engineering, Xi' an Technological University, No. 2 of Xuefu Road in Xi'an, shaanxi, China, E-mail: 1130173978 @ qq.com

${ }^{4}$ School of Civil and Architecture Engineering, Xi'an Technological University, No. 2 of Xuefu Road in Xi'an, shaanxi, China, E-mail: 762370193@qq.com
} 


\section{INTRODUCTION}

Along with the rapid urban development and increase in economic activity, the generation of construction and demolition waste has increased substantially in many parts of the world [1-3]. It has been estimated that the annual generation of construction and demolition waste could be as much as 60 million tons in the USA; Europe produces 180 million tons of construction and demolition waste each year [4]; in China, the annual generation of construction and demolition waste reaches 160 million tons, and is increasing with an annual growth rate of $8 \%$ [5]. If not managed properly, this will bring about two serious problems. On one hand, the extraction of natural aggregates, such as crushed rock and river sand will lead to a depletion of natural resources. On the other hand, a large amount of urban demolition and reconstruction will generate a huge amount of waste, which has a significant impact on the environment [6].

The use of recycled aggregates (RA) as replacements for natural aggregates (NA), in construction applications has been considered as one of the most effective approaches for recycling given materials from construction and demolition waste, thus contributing to a greater sustainability in construction [7]. Indeed, extensive scientific research and development work on this subject has been carried out over the last 40 years. According to existing specifications [8-12], there are three main types of RA arising from construction and demolition waste, which, after being subjected to proper beneficiation processes in certified recycling plants, are suitable for the production of structural concrete; these materials are crushed concrete, crushed masonry, and mixed demolition debris $[13,14]$. However, the general conclusion is that recycled coarse aggregates (RCA) have lower properties than corresponding natural coarse aggregate (NCA) concrete and that this decrease is proportional to the replacement level of NA with RCA $[15,16]$. Actually, there are different types of construction and demolition waste and the composites also are complex, which leads to different types of construction and demolition waste with the different properties [17]. Therefore, investigating mechanical properties of recycled aggregate concrete is very important when the types and composites of construction and demolition wastes are different. 
With the scope of this investigation: (1) properties of coarse aggregates, such as specific gravity, water absorption and crushing index are considered; (2) mechanical properties of RAC, such as uniaxial compression strength and tensile splitting strength are investigated when the different waterto-cement ratios and coarse aggregate replacement rate are adopted.

\section{RAW MATERIALS AND TEST PREPARATION}

\subsection{EXPERIMENTAL MATERIALS AND SPECIMENS}

The $\mathrm{C} 25$ concrete used in the experiment was a mixture of ordinary Portland concrete (strength grade $=$ p.o42.5), clean river sand (fineness modulus $=2.72$ ), continuous-grade coarse aggregate (particle diameter $=5 \mathrm{~mm}$ to $25 \mathrm{~mm}$ ) and water. Recycled coarse aggregate is made of waste road concrete. Fig. 1 shows the waste road concrete collection site. These is no technical data about the waste concrete, the core specimen examination indicates that the compression strength of the waste concrete is between 31.2 and $35.5 \mathrm{MPa}$. Table 1 shows the basic properties of coarse concrete.
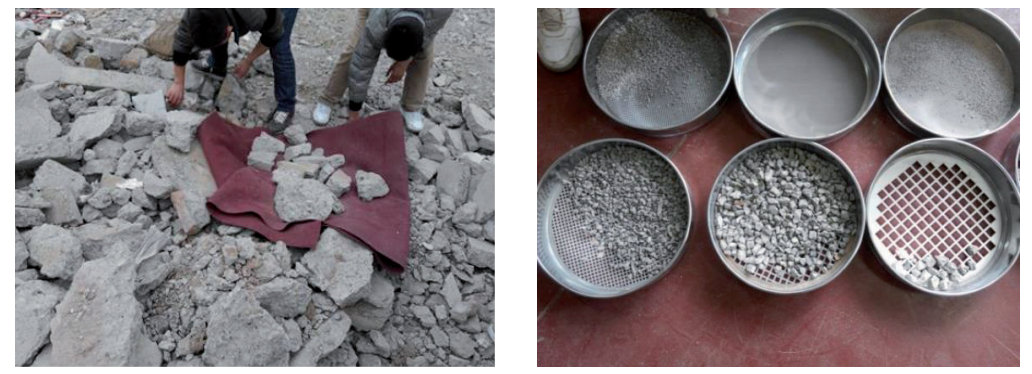

Fig. 1. Selection and screening of waste road concrete

Tab. 1. Basic properties of coarse aggregate

\begin{tabular}{cccccc}
\hline Course aggregate type & $\begin{array}{c}\text { Grading } \\
(\mathrm{mm})\end{array}$ & $\begin{array}{c}\text { Bulk density } \\
\left(\mathrm{kg} / \mathrm{m}^{3}\right)\end{array}$ & $\begin{array}{c}\text { Apparent density } \\
\left(\mathrm{kg} / \mathrm{m}^{3}\right)\end{array}$ & $\begin{array}{c}\text { Absorption } \\
(\%)\end{array}$ & $\begin{array}{c}\text { Crushing index } \\
(\%)\end{array}$ \\
\hline natural & $5.0-25.0$ & 1458 & 2785 & 0.45 & $17.7-19.17$ \\
\hline recycled & $5.0-25.0$ & 1389 & 2534 & 5.32 & $19.8-20.77$ \\
\hline
\end{tabular}


As shown in Table 1, compared with the natural coarse aggregate, the recycled form has lower density, higher absorption, and a higher crushing index, which indicates that the recycled coarse aggregate has high porosity and low strength. This is mainly because the surface of the recycled coarse aggregate is covered by large amount of cement mortar and this result is consistent with previous results [18].

\subsection{SPECIMENS AND NUMBERING OF SPECIMENS}

In this paper, RCA replacement percentage is defined as the ratio of the mass of RCA to the total mass of coarse aggregates used in the concrete. The five RCA replacement percentages, i.e., $0 \%, 25 \%$, $50 \%, 75 \%$, and $100 \%$ were used in the tests; the corresponding specimens in natural dried conditions were named NAC, RAC25, RAC50, RAC75, and RAC100 respectively. Due to the high water absorption of RCA, it was necessary to increase the total quantity of water added to assure the same effective water-to-cement ratio. This fraction of the water is called additional water, which was calculated from the measured effective water absorption (the water absorption from the natural state to the saturated dry surface) of the aggregates. The measured effective water absorption of the RCA in the test was about $5.32 \%$. The additional water is added and mixed with the RCA before the test. The mixture proportions of the concretes are listed in Table 2.

Tab. 2. Mix proportions of concretes

\begin{tabular}{cccccccc}
\hline Specimen & w/c & $\begin{array}{c}\text { Cement } \\
\left(\mathrm{kg} / \mathrm{m}^{3}\right)\end{array}$ & $\begin{array}{c}\text { Sand } \\
\left(\mathrm{kg} / \mathrm{m}^{3}\right)\end{array}$ & $\begin{array}{c}\text { NCA } \\
\left(\mathrm{kg} / \mathrm{m}^{3}\right)\end{array}$ & $\begin{array}{c}\text { RCA } \\
\left(\mathrm{kg} / \mathrm{m}^{3}\right)\end{array}$ & $\begin{array}{c}\text { Mixing water } \\
\left(\mathrm{kg} / \mathrm{m}^{3}\right)\end{array}$ & $\begin{array}{c}\text { additional water } \\
\left(\mathrm{kg} / \mathrm{m}^{3}\right)\end{array}$ \\
\hline NAC-A & 0.47 & 457 & 622 & 1106 & 0 & 215 & 0 \\
\hline RAC-A-25 & 0.47 & 457 & 622 & 830 & 276 & 215 & 14.68 \\
\hline RAC-A-50 & 0.47 & 457 & 622 & 553 & 553 & 215 & 29.42 \\
\hline RAC-A-75 & 0.47 & 457 & 622 & 276 & 830 & 215 & 44.16 \\
\hline RAC-B-100 & 0.47 & 457 & 622 & 0 & 1106 & 215 & 58.84 \\
\hline NAC-B & 0.55 & 391 & 664 & 1130 & 0 & 215 & 0 \\
\hline RAC-B-25 & 0.55 & 391 & 664 & 848 & 282 & 215 & 15.00 \\
\hline RAC-B-50 & 0.55 & 391 & 664 & 565 & 565 & 215 & 30.06 \\
\hline RAC-B-75 & 0.55 & 391 & 664 & 282 & 848 & 215 & 45.11 \\
\hline RAC-B-100 & 0.55 & 391 & 664 & 0 & 1130 & 215 & 60.12 \\
\hline NAC-C & 0.61 & 352 & 733 & 1100 & 0 & 215 & 0 \\
\hline RAC-C-25 & 0.61 & 352 & 733 & 825 & 275 & 215 & 14.63 \\
\hline
\end{tabular}




\begin{tabular}{cccccccc}
\hline RAC-C-50 & 0.61 & 352 & 733 & 550 & 550 & 215 & 29.26 \\
\hline RAC-C-75 & 0.61 & 352 & 733 & 275 & 825 & 215 & 43.89 \\
\hline RAC-C-100 & 0.61 & 352 & 733 & 0 & 1100 & 215 & 58.52 \\
\hline
\end{tabular}

Under the conditions that the water-to-cement ratio is $0.47,0.55$, and 0.61 , concrete specimens with RCA concrete replacement ratio being $0 \%, 25 \%, 50 \%, 75 \%$, and $100 \%$ of the NCA concrete are prepared. The final specimen is a cube measuring $150 \times 150 \times 150 \mathrm{~mm}$. There are 6 specimens prepared for each recycled coarse aggregate concrete replacement ratio; there are 90 concrete specimens in total. The cube is removed 24 hours after it is set, and the specimens are cured in condition of the temperature being $20^{\circ} \mathrm{C}$ and humidity being $90 \%$ for 28 days, then the test is carried out.

Two batches of concrete prismoid specimens were prepared. The first batch of specimens was subjected to the uniaxial compression test. The second batch of specimens was subjected to the tensile splitting test. All specimens were numbered with the appropriate $\mathrm{Y}+$ water-cement ratio + recycled aggregate replacement ratio + serial number and $\mathrm{P}+$ water-cement ratio + recycled aggregate replacement ratio + serial number, where $\mathrm{C}$ and $\mathrm{T}$ represented the uniaxial compression test and the tensile splitting test respectively, and A, B, C represented $0.47,0.55,0.61$ of the water-to-cement ratio and the serial number denoted the specimen number in the same group.

\subsection{EXPERIMENTAL CONTENTS}

The test items analyzed were as follows: (1) The prism compression strength of recycled aggregate concrete was tested when the $0.47,0.55,0.61$ of the water-to-cement ratios and the $0 \%$, $25 \%, 50 \%, 75 \%$, and $100 \%$ of aggregate replacement rate were adopted. (2) The prism tensile strengths of recycled aggregate concrete was tested when the $0.47,0.55,0.61$ of the water-to-cement ratios and the $0 \%, 25 \%, 50 \%, 75 \%$, and $100 \%$ of aggregate replacement rate were adopted. 


\section{PROCEDURES AND RESUlt ANALYSIS OF THE TEST}

\subsection{PRISM UNIAXIAL COMPRESSION TEST}

(1) The procedure of the uniaxial compression test

After curing the specimen for 28 days in standard conditions, the cube compression strength test is conducted according to the Standard for Test Method of Mechanical Properties on Ordinary Concrete (GB/ T 50081-2002) [19]. The loading speed of the test machine is $5 \mathrm{KN} / \mathrm{s}$. When the specimen is about to fail and deforms sharply, the accelerator of test machine is held until it fails and records the failure load.

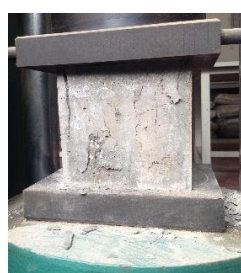

a. $\mathrm{w} / \mathrm{c}$ ratio 0.47 and aggregate replacement rate $50 \%$

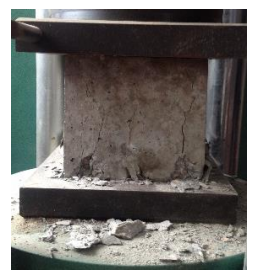

b. $\mathrm{w} / \mathrm{c}$ ratio 0.55 and aggregate replacement rate $50 \%$

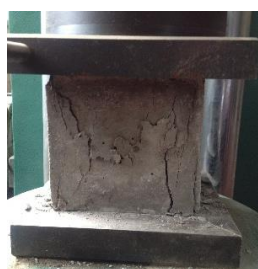

c. $w / c$ ratio 0.61 and aggregate replacement rate $50 \%$

Fig. 2. Uniaxial compression test procedure of specimens with an aggregate replacement rate $50 \%$

During the test, as the load increases, cracks occur near the lateral surface of the specimen and connect with each other. As the increase of force continues, the surface concrete starts to bulge and spall, finally forming a square pyramid. Fig. 2 shows the uniaxial compression test of 3 cubic specimens with water-to-cement ratios of $0.47,0.55$, and 0.61 respectively, and a coarse aggregate replacement rate of $50 \%$.

The failure patterns of the RAC specimens with different RCA replacement percentages were similar to each other in all tests. It was observed that most cracks extended in a manner parallel to the compressive loading. There were always several main cracks running through the specimens. The edges along the top were crushed in some specimens. Most of the cracks passed through the interfaces, 
including the matrix-NCA interfaces, the matrix-RCA interfaces, and the old mortar-original NCA interfaces in the RCA. A few fractured NCA particles including the new NCA and the original NCA in RAC were found at the failure surface.

(2) Results analysis of the uniaxial compression test

A uniaxial compression strength test was conducted for $\mathrm{C} 25$ concrete specimens having different replacement ratios under three different water-to-cement ratios, the test results are shown as Fig. 3. According to the statistics of the results of the test, average values and standard deviations of uniaxial compression strength of cubic specimens having different replacement ratio under different water-tocement ratios were calculated, thereby the average value of the uniaxial compression strength of 15 sets of specimens was obtained. Fig. 4 shows the line graph of the uniaxial compression strength.

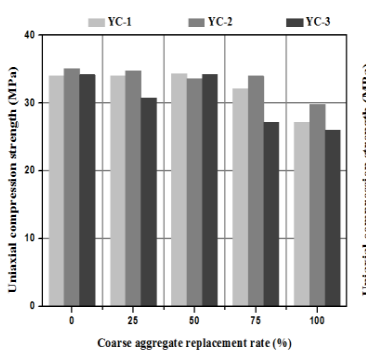

a. 0.47 water-cement ratio

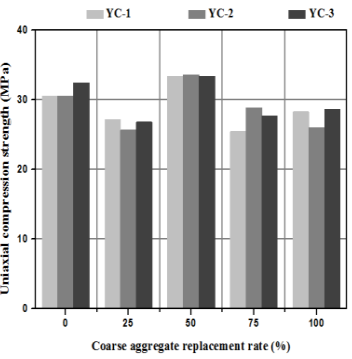

b. 0.55 water-cement ratio

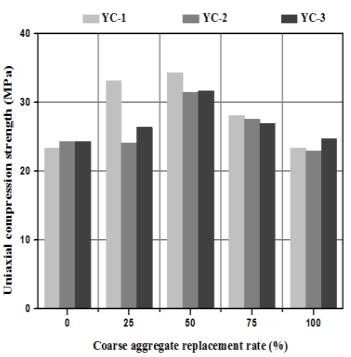

c. 0.61 water-cement ratio

Fig. 3. Uniaxial compression strength of specimens under three different water-to-cement ratios

As shown in Figure 4 and Figure 3, when the water-to-cement ratio increases from 0.47 to 0.61 , the uniaxial compression strength of the concrete specimen decreases. This indicates that increasing the water-to-cement ratio obviously decreases the compression strength of the recycled concrete. When the specimens have the same water-to-cement ratio, and the coarse aggregate replacement rate changes from $0 \%$ to $50 \%$, the uniaxial compression strength of the RCA specimen does not change much when compared to the NCA specimen. This phenomenon is similar to what was found in other experimental studies [20].

Compared with the NCA, the water absorption of the RCA increases because the RCA contains a certain amount of cement particles on its surface and internal micro cracks produced in the process of fragmentation. With the increase of the coarse aggregate replacement rate, the water absorbed by 
each specimen increases, and the absorption speed is fast; it happens before the hardening of the concrete mixture. In spite of adding the additional water fraction, the actual water-to-cement ratio has decreased. The reduction of the actual water-to-cement ratio causes the concrete strength to increase. From this perspective, the strength of recycled concrete increases as the coarse aggregate replacement rate increases. When the recycled coarse aggregate replacement rate increases beyond $50 \%$, internal micro-cracks show great influence on the mechanical properties of specimens which causes the uniaxial compression strength of specimens to reduce obviously. Thereby this is the possible answer as to why the coarse aggregate prepared with 50\% NCA and 50\% RCA shows an increase in strength.

As we can see from the experimental results in Figure 4, when the recycled coarse aggregate replacement rate is $50 \%$, the uniaxial compression strength of specimens increases a lot compared with the uniaxial compression strength when the replacement rates are $0 \%$ and $25 \%$. When the recycled coarse aggregate replacement rate exceeds $50 \%$, the uniaxial compression strength of the specimens decreases obviously.

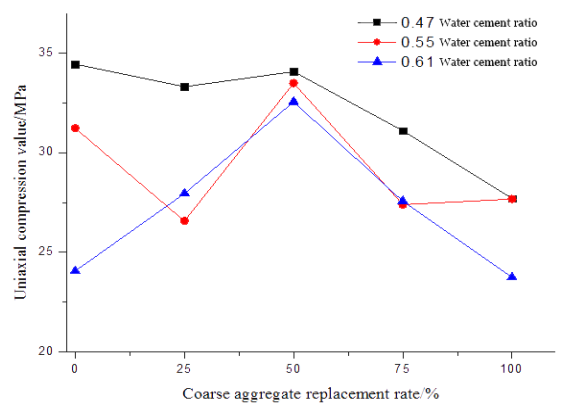

Fig. 4. Uniaxial compression (average strength) of specimens under three different water-to-cement ratios

However, when the coarse aggregate replacement rate increases to $75 \%$ and $100 \%$, the uniaxial compression strength of recycled aggregate concrete under three water-to-cement ratios decreases obviously. Compared with the uniaxial compression strength of RCA specimens when the coarse aggregate replacement rate is $50 \%$, the uniaxial compression strength of RCA specimens is reduced by $8.72 \%, 18.21 \%$ and $15.29 \%$ respectively under three water-to-cement ratios when the replacement rate is $75 \%$. The uniaxial compression strength of the RCA specimen is reduced by $18.54 \%, 17.38 \%$, 
and $27.07 \%$ respectively when the coarse aggregate replacement rate is $100 \%$. The test results show that when the coarse aggregate replacement rate exceeds $50 \%$, the uniaxial compression strength of RCA specimens decreases rapidly. Thereby the water-to-cement ratio and the coarse aggregate replacement rate has a large impact on the uniaxial compression strength of RCA specimens.

\subsection{PRISM TENSILE SPLITTING TEST}

(1) Procedure of the tensile splitting test

After curing the specimen for 28 days in standard conditions, the prism tensile splitting test is conducted according to the Standard for test method of mechanical properties on ordinary concrete (GB/T 50081-2002). The loading speed of the test machine is $5 \mathrm{KN} / \mathrm{s}$. When the specimen is about to fail and deforms sharply, the accelerator of test machine is held until it fails and records the failure load.

During the tensile splitting test, no cracks are found on the surface of the RAC specimens at the beginning of loading. As the load increases, the stress inside the specimen increases continuously and cracks occur on lateral surface of the specimen. The cracks first occur in the middle of the specimen, and, as the increase continues, cracks develop near the filler strip. As the load increases continuously, the width of the cracks in the middle of the concrete expands gradually; finally, the concrete is split. During the tensile splitting tests the specimens were all tested at the same loading velocity. It was observed that the failure patterns of the RCA specimens with different RCA replacement percentages are similar to those of the NAC specimens. However, the fractured NCA particles still made up only a small proportion of the total aggregate particle amount at the fractured surface. Moreover, most of the fractured NCA particles were elongated aggregates rather than rounded aggregates. To sum up, most of the cracks still passed through the interfaces.

(2) Results analysis of the tensile splitting test

After conducting the tensile splitting test for $\mathrm{C} 25$ concrete specimens with different replacement rates in three water-to-cement ratios, the test results are shown as Fig.5 and Fig.6. 


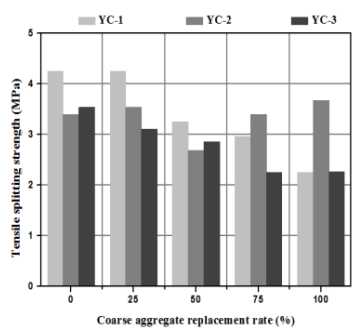

a. 0.47 water-cement ratio

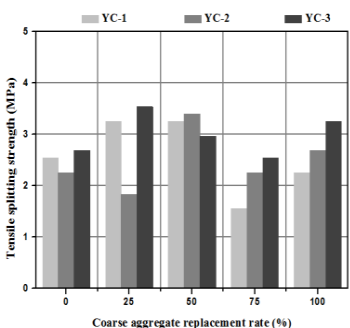

b. 0.55 water-cement ratio

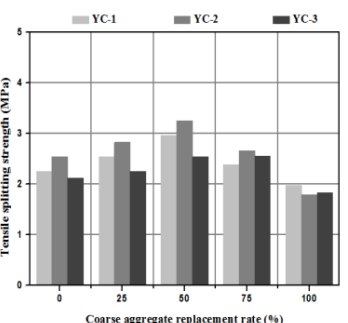

c. 0.61 water-cement ratio

Fig. 5. Tensile splitting strength of specimens under three different water-to-cement ratios

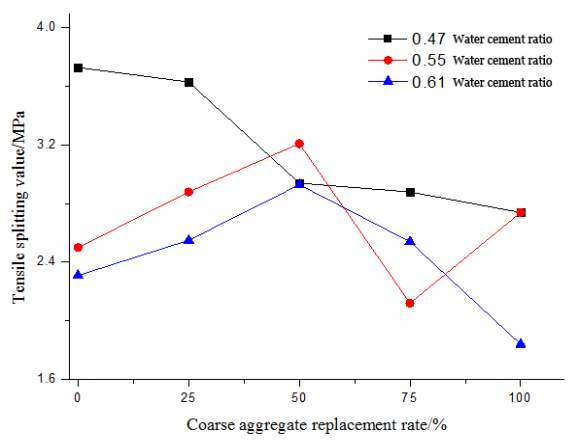

Fig. 6. Tensile splitting strength of specimens under three different water-to-cement ratios

As shown in Fig. 5 and Fig. 6, when the water-to-cement ratio increases from 0.47 to 0.61 , the tensile splitting strength of the concrete specimen decreases obviously. This indicates a similar rule as that of the uniaxial compression strength: when the coarse aggregate replacement rate increases from $0 \%$ to $50 \%$, the tensile splitting strength of RCA specimens under three water-to-cement ratios irregularly changes. When the water-to-cement ratio is 0.47 , the tensile splitting strength of the RCA specimen is reduced by $2.68 \%$ and $21.18 \%$ on average compared with that of the RCA specimen with a $0 \%$ coarse aggregate replacement rate. However, the tensile splitting strength of the RCA specimens increases on average when the water-to-cement ratio is 0.55 and 0.61 , respectively. However, when the coarse aggregate replacement rate increases to $75 \%$ and $100 \%$, the tensile splitting strength of the RCA specimen under three water-to-cement ratios decreases obviously. Compared with the tensile splitting strength of the RCA specimen when the coarse aggregate replacement rate is $50 \%$, the tensile 
splitting strength of the RCA specimen is reduced by $2.04 \%, 33.96 \%$ and $13.31 \%$ respectively under three water-to-cement ratios when the coarse aggregate replacement rate is $75 \%$. The tensile splitting strengths of the RCA specimens are reduced by $7.14 \%, 14.64 \%$, and $37.20 \%$ respectively when the coarse aggregate replacement rate is $100 \%$. The test results show that the higher the water-to-cement ratio and coarse aggregate replacement rate, the higher reduction rate for tensile splitting strength of the RCA specimen decreases rapidly. Thereby, the water-to-cement ratio and coarse aggregate replacement rate has a large impact on the tensile splitting strength of the RCA specimen. When the recycled coarse aggregate replacement rate is $50 \%$, the tensile splitting strength of specimens increases a lot when the water-to-cement ratio is 0.55 and 0.61 , and the possible reason for this observation is the same as the previous explanation of the increase of the uniaxial compression strength.

\section{CONCLUSIONS}

In this study, the basic properties of aggregates, such as specific gravity, water absorption, and crushing index are considered. Meanwhile, mechanical properties of RCA concrete such as compression strength and tensile strength are investigated when the different water-to-cement ratios and aggregate replacement rates are adopted. From the experimental laboratory-based work carried out in this study, the main conclusions drawn were as follows:

(1) The uniaxial compression strength and tensile splitting strength of RCA specimens decreases with the increase of the $\mathrm{w} / \mathrm{c}$ ratio as the same condition. Therefore, reducing the $\mathrm{w} / \mathrm{c}$ ratio of recycled aggregate concrete mixes is an effective method to increase the mechanical performance of RCA specimens.

(2) For recycled aggregate concrete with the same water-to-cement ratio, when the coarse aggregate rate changes from $0 \%$ to $50 \%$, the uniaxial compression strength changes a little and tensile splitting strength irregularly changes when compared with those made of natural coarse aggregate concrete. When the coarse aggregate rate changes from $50 \%$ to $100 \%$, the uniaxial compression strength and tensile splitting strength of RCA specimens decreases rapidly.

(3) From the results of the uniaxial compression and tensile splitting tests, we see that when the 
coarse aggregate replacement rate is $50 \%$, the uniaxial compression and tensile splitting strength of the RCA specimens with different water-to-cement ratios are relatively close. However, the uniaxial compression and tensile splitting strength of the RCA specimens with different water-to-cement ratios are staggered under the other coarse aggregate replacement rate. As a result, when the coarse aggregate replacement rate is $50 \%$, the water-to-cement ratio has little influence on mechanical properties of the recycled coarse aggregate concrete.

\section{ACKNOWLedgments}

This research was financially supported by the National Natural Science Foundation of China (NSFC. Grant Nos. 51408054 sponsored), the Scientific Research Foundation (15JK1337), the Education Department of Shaanxi Province, and the Scientific Research Program(KLTLR-Y14-15) for Technology of Highway Construction and Maintenance Technology of National Transportation Industry Key Laboratory.

\section{REFERENCES}

1. A. Rao, K. N. Jha, S. Misra. "Use of aggregates from recycled construction and demolition waste in concrete", Resources Conserve Recycle, 50(1), 71-81, 2007.

2. A. Coelho, J. D. Brito. "Economic analysis of conventional versus selective demolition-a case study", Resources Conserve Recycle, 55(3), 382-92, 2011.

3. R. V. Silva, R. Neves, J de Brito, R. K. Dhir. "Carbonation behaviour of recycled aggregate concrete", Cement and Concrete Composites, 62, 22-32, 2015.

4. V. Radonjanin, M. Malešev, S. Marinković, A. E. S. A.1 Malty. "Green recycled aggregate concrete", Construction and Building Materials, 47, 1503-1511, 2013.

5. H. B. Zhu, Y. Zhao, X. W. Lei, Q. Yang. "Current situation and suggestion on recycled concrete research", Highway Engineering, 38(1), 98-103, 2013. (in Chinese)

6. L. Evangelista, J. de Brito. "Durability performance of concrete made with fine recycled concrete aggregates", Cement Concrete Composites, 32(1), 9-14, 2010.

7. KK. Sagoe-Crentsil, T. Brown, AH. Taylor. "Performance of concrete made with commercially produced coarse recycled concrete aggregate", Cement Concrete Research, 31(5), 707-712, 2001.

8. BCSJ. "Proposed standard for the use of recycled aggregate and recycled aggregate concrete", Committee on Disposal and Reuse of Construction Waste, BCSJ, Tokyo, Japan, 1977.

9. BRE. "Recycled aggregates", Wikipedia, Building Research Establishment, London, UK, 1998.

10. PTV-406. "Recycled aggregates from construction and demolition wastes (in French)”, PTV, Brussels, Belgium, 2003. 
11. WBTC-No.12. "Specifications facilitating the use of recycled aggregates", Works Bureau Technical Circular, Hong Kong, China, 2002.

12. JIS-5023. "Recycled aggregate for concrete-class L", Japan Standards Association, Tokyo, Japan, 2012.

13. K. Amnon. "Properties of concrete made with recycled aggregate from partially hydrated old concrete", Cement Concrete Research, 33(5), 703-711, 2003.

14. R. Khaldoun. "Mechanical properties of concrete with recycled coarse aggregate", Building and Environment, 42(1), 407-415, 2007.

15. K. Rahal. "Mechanical properties of concrete with recycled coarse aggregate", Building Environment, vol. 42, 407-15, 2007.

16. SW. Tabsh, AS. Abdelfatah. "Influence of recycled concrete aggregates on strength properties of concrete", Construction and Building Materials, vol. 23, 1163-1167, 2009.

17. MC. Rao, SK. Bhattacharyya, SV. Barai. "Influence of field recycled coarse aggregate on properties of concrete", Materials and Structures, vol. 44, 205-211, 2011.

18. X. P. Li. "Study on mechanical properties of recycled aggregate concrete(I) - behaviour under uniaxial compression", Journal of Building Materials, 10(5), 598-604, 2007. (in Chinese)

19. GB/T 50081-2002. "Standard for Test Method of Mechanical Properties on Ordinary Concrete", Beijing: China Architecture and Building Press, 2002.

20. J. Z. Xiao, L. Li, L. M. Shen, C. S. Poon. "Compressive behaviour of recycled aggregate concrete under impact loading”, Cement and Concrete Research, vol. 71, 46-55, 2015.

Received 13.06.2016

Revised 29.07.2016 


\section{LIST OF FIGURES AND TABLES:}

Fig. 1. Selection and screening of waste road concrete

Rys. 1. Wybór i odsiewanie odpadów betonu drogowego

Fig. 2. Uniaxial compression test procedure of specimens with aggregate replacement rate $50 \%$

Rys. 2. Procedura próby ściskania jednoosiowego próbek o łącznym wskaźniku zamiany kruszywa 50\%

Fig. 3. Uniaxial compression strength of specimens under three different water-to-cement ratios

Rys. 3. Jednoosiowa wytrzymałość na ściskanie próbek w trzech różnych proporcjach wody do cementu

Fig. 4. Uniaxial compression average strength of specimens under three different water-to-cement ratios

Rys. 4. Średnia jednoosiowa wytrzymałość na ściskanie próbek w trzech różnych proporcjach wody do cementu

Fig. 5. Tensile splitting strength of specimens under three different water-to-cement ratios

Rys. 5. Wytrzymałość na rozciąganie przez rozłupywanie próbek w trzech różnych proporcjach wody do cementu

Fig. 6. Tensile splitting strength of specimens under three different water-to-cement ratios

Rys. 6. Wytrzymałość na rozciąganie przez rozłupywanie próbek w trzech różnych proporcjach wody do cementu

Tab. 1. Basic properties of coarse aggregate

Tab. 1. Podstawowe właściwości kruszywa gruboziarnistego

Tab. 2. Mix proportions of concretes

Tab. 2. Proporcje mieszanek betonów 


\section{BADANIA WLAŚCIWOŚCI MECHANICZNYCH BETONU KRUSZYWOWEGO WTÓRNEGO WYKONANEGO Z UŻYCIEM KRUSZYWA GRUBOZIARNISTEGO TAKŻE POCHODZENIA WTÓRNEGO}

Słowa kluczowe: beton z kruszywa gruboziarnistego poddanego recyklingowi; stosunek wody do cementu; wskaźnik zamiany kruszywa gruboziarnistego; jednoosiowa wytrzymałość na ściskanie; wytrzymałość na rozciąganie przez rozłupywanie

\section{STRESZCZENIE:}

Recykling odpadów budowlanych oraz materiałóa)w pochodzących z rozbiórek nie tylko zmniejsza koszty projektu i oszczędza zasoby naturalne, ale również zażegnuje zagrożenie dla środowiska spowodowane przez składowanie odpadów budowlanych. Szczególnie w odniesieniu do właściwości mechanicznych betonu z kruszywa gruboziarnistego poddanego recyklingowi, odpady betonu drogowego C25 są używane jako materiał eksperymentalny, pod warunkiem że stosunek wody do cementu wynosi $0,47,0,55$ i 0,61 oraz są przygotowane próbki betonu o wskaźniku zamiany betonu z kruszywa gruboziarnistego poddawanego recyklingowi wynoszącym $25 \%, 50 \%, 75 \%$ i $100 \%$ betonu z naturalnego kruszywa gruboziarnistego. Próbka to sześcian o wymiarach $150 \times 150 \times 150 \mathrm{~mm}$. Przygotowaliśmy 6 próbek dla każdego wskaźnika zamiany betonu z kruszywa gruboziarnistego poddawanego recyklingowi. Przygotowano łącznie 90 próbek betonu. Próbki zostały usunięte 24 godziny po ustawieniu oraz były utwardzane w temperaturze $20^{\circ} \mathrm{C}$ i wilgotności $90 \%$ przez 28 dni. Następnie przeprowadzono próby ściskania jednoosiowego oraz wytrzymałości na rozciąganie przez rozłupywanie betonu z kruszywa poddawanego recyklingowi C25.

Podczas próby jednoosiowego ściskania, pojawiały się połączone ze sobą pęknięcia blisko powierzchni bocznej próbki w miarę wzrostu obciążenia. Wraz z wzrostem obciążenia, powierzchnia betonu zaczynała się nabrzmiewać i odpryskiwać, tworząc na końcu piramidę z kwadratową podstawą. Podczas próby wytrzymałości na rozciąganie przez rozłupywanie betonu nie znaleziono pęknięć na powierzchni próbek kruszywa poddanego recyklingowi na początku obciążania. W miarę zwiększenia obciążenia, naprężenie wewnątrz próbki stale się zwiększało oraz pojawiły się pęknięcia na powierzchni bocznej próbki. Pęknięcia po raz pierwszy wystąpiły w środku próbki. W miarę wzrostu obciążenia, pęknięcia pojawiały się blisko listwy wypełniającej. Wraz z ciągłym wzrostem obciążenia, szerokość pęknięć na środku betonu powiększała się stopniowo i ostatecznie beton rozłupał się.

W tym badaniu wzięto pod uwagę podstawowe właściwości kruszyw, takie jak ciężar właściwy, absorpcja wody i wskaźnik kruszenia. Tymczasem właściwości mechaniczne betonu z kruszywa poddanego recyklingowi, takie jak wytrzymałość na ściskanie i wytrzymałość na rozciąganie, poddano badaniu po przyjęciu różnych stosunków wody do cementu i zamian kruszywa. Z przeprowadzonych eksperymentalnych prac laboratoryjnych przeprowadzonych w ramach 
niniejszego artykułu wyciągnięto następujące wnioski: (1) Jednoosiowa wytrzymałość na ściskanie i wytrzymałość na rozciąganie przez rozłupywanie spadały wraz ze wzrostem udziału betonu z kruszywa poddanego recyklingowi; (2) W przypadku betonu z kruszywa poddanego recyklingowi o tych samych stosunkach wody do betonu, gdy udział kruszywa gruboziarnistego zmieniał się z $0 \%$ do 50\%, jednoosiowa wytrzymałość na ściskanie zmieniała się trochę, a wytrzymałość na rozciąganie przez rozłupywanie zmieniała się nieregularnie w porównaniu z betonem $\mathrm{z}$ naturalnego kruszywa gruboziarnistego. Gdy udział kruszywa gruboziarnistego zmieniał się z 50\% do 100\%, jednoosiowa wytrzymałość na ściskanie i wytrzymałość na rozciąganie przez rozłupywanie próbek RCA nagle spadły. (3) Na podstawie wyników prób jednoosiowego ściskania i rozciągania przez rozłupywanie widzimy, że gdy wskaźnik zamiany kruszywa gruboziarnistego wynosi $50 \%$, jednoosiowe ściskanie i wytrzymałość na rozciąganie przez rozłupywanie próbek RCA o różnych stosunkach wody do cementu są stosunkowo zbliżone. Jednak jednoosiowe ściskanie i wytrzymałość na rozciąganie przez rozłupywanie próbek RCA o różnych stosunkach wody do cementu są rozłożone w ramach innych wskaźników zamian kruszywa gruboziarnistego. W rezultacie gdy zamiana kruszywa gruboziarnistego wynosi $50 \%$, stosunek wody do cementu ma niewielki wpływ na właściwości mechaniczne betonu z kruszywa gruboziarnistego poddanego recyklingowi. 